\section{Leaf Blower Adapted for Large-scale Inoculation of Plants with Mechanically Transmitted Viruses}

\author{
Henry M. Munger, Yiping Zhang, Susan L. Fenton, and Molly Kyle \\ Department of Plant Breeding and Biometry, Cornell University, Ithaca, \\ NY 14853
}

\begin{abstract}
Additional index words. virus resistance, seedling screen, disease resistance, inoculum blower
\end{abstract}

\begin{abstract}
Plants to be screened for resistance to mechanically transmitted viruses can be inoculated by using an inexpensive electric-powered leaf blower. This device greatly reduces the amount of time to inoculate large populations when compared with handrubbing methods. No significant differences were noted with regard to the frequency of seedlings that escaped infection.
\end{abstract}

An electric-powered leaf blower designed for lawn use can be modified to serve as an inexpensive and convenient device for inoculating large plant populations to screen for resistance to viral diseases. Similar techniques have been used successfully for large-scale inoculation by several investigators (Dean, 1960; Lindner and Kirkpatrick, 1959; McKinney and Fellows, 1951; Richards and Munger, 1944). However, each of the devices required a source of compressed air.

When thousands of seedlings must be evaluated, hand-rubbing inoculation in a greenhouse is extremely time- and labor-intensive. Also, symptom severity may differ among seedlings inoculated by different individuals working side by side using the same inoculum and inoculation techniques.

We report here the adaptation and use of an electric inoculum blower for rapid large-scale inoculation of mechanically transmissible plant viral diseases.

\section{Materials and Methods}

Inoculum with adequate virus concentration is essential for the blower method of application. We have prepared inoculum for up to 1000 seedlings from $\approx 40$ susceptible squash plants (Cucurbita pepo L.) grown in two greenhouse flats with total area $\approx 2500$ $\mathrm{cm}^{2}$. Plants for inoculum were inoculated at the one to two true-leaf stage, 1 to 2 weeks before the test seedlings reached the one to two

\footnotetext{
Received for publication 17 June 1995. Accepted for publication 18 July 1995. We thank J.D. McCreight for critical review of the manuscript. This publication was supported by U.S. Dept. of Agriculture National Research Institute Award no. 94-37300-0333, the California Melon Research Board, and by the Office of USAID/CAIRO/AGR/A under Cooperative Agreement no. 263-0152-A-003036-00. The cost of publishing this paper was defrayed in part by the payment of page charges. Under postal regulations, this paper therefore must be hereby marked advertisement solely to indicate this fact.
}

true-leaf stage. Tissue from strongly symptomatic young plants was macerated in a blender with the addition of $0.05 \mathrm{~m}$ potassium phosphate buffer, $\mathrm{pH}=7.0$. Sap was filtered through cheesecloth and diluted with distilled water to a volume of 2 to 3 liters, depending on age of tissue and number of plants to be inoculated. While the precise titer of virus will vary from preparation to preparation, we have achieved consistent results using this procedure for inoculum preparation.

When using the blower (Fig. 1), inoculum was placed in a 500-ml plastic squeeze bottle connected by a rubber tube to a blue pipette tip (Pipetman automatic pipetor; Rainin Instruments, Woburn, Mass.) taped to the air outlet of a Toro model 550 TBX leaf blower (Fig. 1). About $2 \mathrm{~g}$ of 320 -grit carborundum was added to each $500 \mathrm{ml}$ of inoculum as an abrasive with the amount determined by the tenderness of the seedlings. The blower was held with one hand and the squeezable inoculum container in the other. The container was continuously shaken to keep the carborundum in suspension while squeezing the container controlled the flow of inoculum into the air stream. Alternatively, the leaf blower can be mounted so that the inoculum container remains above the level of the spray nozzle and is shaken during application.

\section{Results and Discussion}

Best results were obtained when the air outlet was held 20 to $50 \mathrm{~cm}$ from the leaves (based on the size and tenderness of the seedlings) and the high-speed setting was used. Leaves were sprayed thoroughly and evenly from various directions, returning the air blast to each plant two to three times. The appearance of water-soaked spots on leaves indicated sufficient exposure. Spray application was stopped when these spots were visible to reduce damage that could obscure symptoms or decrease consistency. The intensity of the inoculation can be adjusted by the speed at which the nozzle is moved, and the distance between the spray nozzle and the target plants. Immediately after inoculation, the plants were rinsed by adding water to the airstream of the blower and holding the outlet 1 to $2 \mathrm{~m}$ from the plants. We have achieved best results with the blower when inoculations were repeated once or twice after the initial inoculation at $\approx 1$ - to 2 week intervals.

We have used this device successfully to infect melon (Cucumis melo L.), cucumber ( $C$. sativus L.), and squash with cucumber mosaic virus, watermelon mosaic virus, papaya ringspot virus, and zucchini yellow mosaic virus, with an infection frequency of $95 \%$ to $100 \%$ (Table 1), similar to or greater than we generally observe with the conventional rubbing method (between $90 \%$ to $100 \%$ ). Counts were made in three melon breeding populations after two inoculations. Since even the most resistant plants showed some initial symptoms followed by recovery, plants with com-

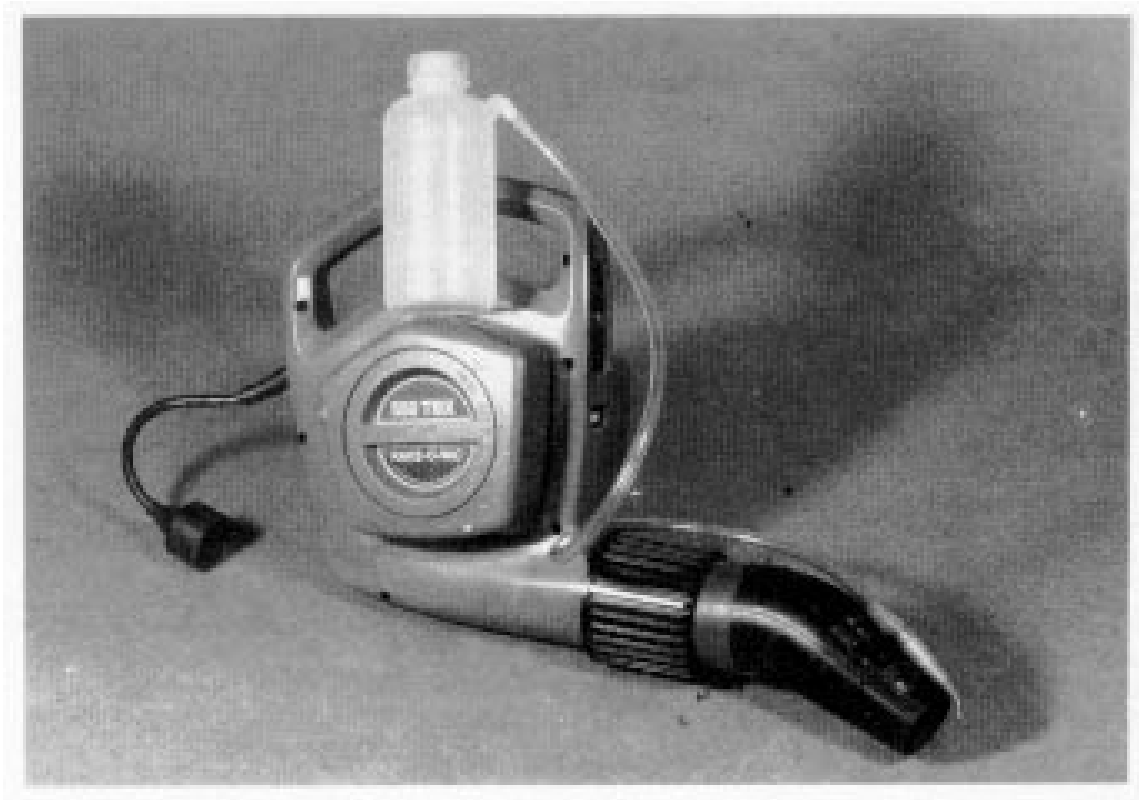

Fig. 1. Electric leaf blower adapted for use in large-scale plant virus inoculations. 
Table 1. Comparison of inoculation effectiveness and rates between inoculation via hand-rubbing and inoculation using the modified leaf blower on Cucumis species.

\begin{tabular}{|c|c|c|c|c|c|}
\hline Host plant genotype & Method & Virus $^{2}$ & $\begin{array}{l}\text { No. } \\
\text { plants }\end{array}$ & $\begin{array}{c}\text { Time of } \\
\text { blowing } \\
(\mathrm{min})\end{array}$ & $\begin{array}{c}\text { Infection } \\
(\%)\end{array}$ \\
\hline \multirow[t]{2}{*}{ C. melo PMR cv. Iroquois ${ }^{\mathrm{y}}$} & Blower & CMV & 60 & 2 & 100 \\
\hline & Hand & CMV & 60 & 9 & 97 \\
\hline \multirow[t]{2}{*}{ C. sativus cv. Marketer ${ }^{\mathrm{y}}$} & Blower & CMV & 60 & 2 & 100 \\
\hline & Hand & CMV & 60 & 9 & 95 \\
\hline \multirow[t]{3}{*}{ C. melo population } & Blower & CMV & 454 & 8 & 96 \\
\hline & Blower & WMV & 313 & 7 & 97 \\
\hline & Blower & ZYMV & 212 & 5 & 100 \\
\hline
\end{tabular}

${ }^{2} \mathrm{CMV}=$ cucumber mosaic virus; WMV = watermelon mosaic virus; ZYMV = zucchini yellow mosaic virus ${ }^{\mathrm{y}}$ Five replications.

plete lack of symptoms were considered escapes, which ranged from $0 \%$ to $4 \%$ in these cases. Twelve plants each of susceptible cucumbers and melons were planted at each end of five flats, with one end inoculated by hand and then covered, while the other end was inoculated by blower, giving a randomized split-plot design. Counts were made after a single inoculation. The $100 \%$ infection obtained with the blower vs. $95 \%$ and $97 \%$ for hand inoculation was not always found in large-scale plantings. The lack of significant difference was, however, in line with our general experience with the two inoculation methods. The blower method offers relatively little advantage when few seedlings (e.g., 100 or fewer) are to be screened. However, $>1000$ plants can be inoculated in $20 \mathrm{~min}$, instead of several hours required for conventional rubbing inoculation. The use of the blower inoculation technique has significantly decreased the labor devoted to greenhouse screens for virus resistance and has allowed us to use larger plant populations and more viruses.

\section{Literature Cited}

Dean, J.L. 1960. A spray method for inoculating sugarcane seedlings with the mosaic virus. Plant Dis. Rpt. 44:874-876.

Lindner, R.C. and H.C. Kirkpatrick. 1959. The airbrush as a tool in virus inoculations. Phytopathology 49:507-509.

McKinney, H.H. and H. Fellows. 1951. A method for inoculating varietal test nurseries with the wheat streak mosaic virus. Plant Dis. Rpt. 35:264-266.

Richards, B.L., Jr., and H.M. Munger. 1944. A rapid method for mechanically transmitting plant viruses. Phytopathology 34:1010. (Abstr.) 